\title{
The Role of Marketing Information Systems in Reducing the Effects of the International Financial Crisis: A Study Applied on the Banks Working in the Kingdom of Saudi Arabia from Islamic Perspective
}

\author{
Hamdi Jaber Barakat ${ }^{1}$, Hisham Ali Shatnawi ${ }^{1} \&$ Shaker Turki Ismail $^{2}$ \\ ${ }^{1}$ College of Business Administration, Ajloyn National Univerty, Ajlon, Jordan \\ ${ }^{2}$ King Abed Al Azez University, KSA \\ Correspondence: Hamdi Jaber Barakat, College of Business Administration, Ajloyn National Univerty, Ajlon, \\ Jordan. E-mail: hamdibarakat2003@yahoo.com or shatnawi_hisham@yahoo.com
}

\author{
Received: December 9, 2015 Accepted: December 30, 2015 Online Published: January 28, 2016 \\ doi:10.5539/ijms.v8n1p181 URL: http://dx.doi.org/10.5539/ijms.v8n1p181
}

\begin{abstract}
The study aimed to measure the impact of the elements of marketing system in the banks working in Saudi Arabia and its role in meeting the effects of reducing the price of oil by the lawful rules.

The population of the study included three banks in all branches working in Saudi Arabia. The intentional sample was withdrawn for the distribution of the study tool (questionnaire) which included marketing managers, where 89 questionnaires were recovered and 75 questionnaires were appropriate for analysis issues.

The effects of the financial crisis on marketing banks working in Saudi Arabia due to a set of independent variables were formulated as hypotheses represented by: (the dimensions of marketing information systems, the Islamic requirements in marketing the Islamic banks, the core differences between the banks working in Saudi Arabia due to the marketing information systems) in order to measure its impact on the dependent variable (the ability of the banks working in Saudi Arabia to stand up and meet the effects of financial crisis). The hypotheses were selected due to (SPSS) method at the statistical significance 5\%.

The researchers came up with a set of results that supported the hypotheses of the study showing the importance of marketing systems as independent variables in marketing and activating the Islamic financial management in the banks working in Saudi Arabia to prevent the effects of the financial crisis. It was notified that all independent variables that were mentioned above affected the dependent variable. In the light of conclusions, a set of recommendations were provided to enhance the role of marketing information system and activate the marketing of tools of banks working in Saudi Arabia to meet the financial crisis and reduce its effects.
\end{abstract}

Keywords: international financial crisis, marketing information systems, Islamic banks

\section{Introduction}

Marketing information system is considered as one of the most information systems that cannot be refused in the light of expanding and opening new markets. Also, the factor of varying the forms of competition in the light of global challenges is created by the communication revaluation as well as the flow of information and how to retrieve it quickly. The result is that business organizations and marketing managements are commitment to adopt the most developed competitive advantages in the field of information technology which will help them to survive through developing and improving their own capacity to gain the opportunities to address and stand up before the risks that can be met by the management and marketing of the financial crisis resulting from the current international financial crisis as they are the most important tools.

Because of the bad affects of the current financial crisis on the activities of business organizations generally, marketing information systems (MKIS) is the main tool that can reduce the degree of lack of trust in taking the strategic marketing decisions to meet the crisis and working on reducing the effects of its negative consequences to survive.

As mentioned above, the study was prepared to identify the role played by marketing information systems in the banks working in Saudi Arabia to challenge and reduce the effects of the crisis from the Islamic perspective depending on the theoretical framework and practical framework applied on the banks working in Jeddah, Saudi 
Arabia.

\subsection{The Problem of the Study}

According to the destructive effects of the crisis on business organization in general and banking sector in particular, the crisis caused a sudden and unexpected collapse in some international working banks to get out from the sector of industry because of their bankruptcy. So, business organizations in general and banks in particular are commitment to adopt defensive strategies and policies to reduce the effects of the international financial crisis by adopting the Islamic approach in managing the operations and the long run trends.

The problem of the study appeared as a result of the weak interest of the Jeddah banks in marketing information systems. They don't take advantages from them efficiently and effectively confirming with the legal rules to reduce and prevent the effects of the international financial crises. The study will try to answer the following questions:

a) Is there a core difference in the availability of marketing information systems in the banks working in Saudi Arabia?

b) What is the relation between using marketing information system in the banks working in Saudi Arabia and how to reduce the effects of the international financial crisis?

c) What is the Islamic perspective in managing the current crisisto reduce the effects of international financial crisis in banks working in Saudi Arabia?

\subsection{The Importance of the Study}

This study discusses the most important topic related to the reality of the banks working in Saudi Arabia, and particularly to what concerned with the theoretical framework of the current international financial crisis as well as the Islamic perspective for the role of marketing information system. This study is conducted to help the decision makers in the Islamic banks to connect between employing the marketing information systems in financial process and providing financial services due to the rules of Islamic legislation to reduce the effects of the current financial crises.

\subsection{The Objectives of the Study}

The study aimes to identify the role of marketing information systems in banks working in Saudi Arabia to reduce the effects of the international financial crisis, the extent of availability of systems elements, identify the nature of relation between marketing information system and the ability to meet and manage the financial crisis and thus provide a set of recommendations based on the results of the study.

\subsection{The Conceptual Definitions}

1) Information marketing systems:

It is a system consisted of people, devices, and procedures. It is based on collecting, classifying, analyzing, and distributing needed information accurately, and they come in the appropriate time for marketing decision-makers in the organization (Hesham, 2007, p. 61).

2) Islamic financial service:

It is a type of intangible services including tasks, experiences, activities, efforts and the notions cannot be owned by their receivers (AL-hneti, 2007, p. 15).

3) The Islamic banks:

They are banks whose rules are commitment to apply the principles of Islamic legislation and not to deal with the banking interest (Ishmael, 2009, p. 22).

4) The current financial crisis:

It is a financial crisis that appeared at the beginning of 2007 in the US economy which led to a collapse and bankruptcy to many of financial institutions, and accordingly the crisis expanded all over the world (Al-Alian, 2007, p. 19).

\subsection{The Main Hypothesis of the Study}

Hypothesis (1): There are no statistical significant differences between marketing information system and reducing the effects of the international financial crisis in the banks working in Saudi Arabia.

Hypothesis (2): There is a core difference between the banks working in Saudi Arabia and their ability to meet the crisis of the current the international financial crisis. 
Hypothesis (3): There is a core difference in the availability of marketing information system elements in the banks working in Saudi Arabia.

Hypothesis (4): There is a statistical significant difference for marketing information system to reduce the effects of the international financial crisis.

\section{Methodology of the Study}

The researchers have used the descriptive analytical approach that covered the theoretical side of the study through using some resources such as books, periodicals, articles, scientific studies and documents which are related to the same subject to cover all aspects of the study.

As for the practical side, it used the descriptive analytical approach since it was the most appropriate one for this study and this was through analyzing the data by using the statistical package for social sciences (SPSS) in order to get the findings and test the hypotheses of the study.

The researchers also used the approach of making meetings and direct questions for salesmen who are in charge of selling and promoting the therapeutical products of pharmacies and government and private hospitals in addition to owners of therapeutical factories and stores and workers in the field.

A set of independent and dependent variables have been represented by this figure as following:

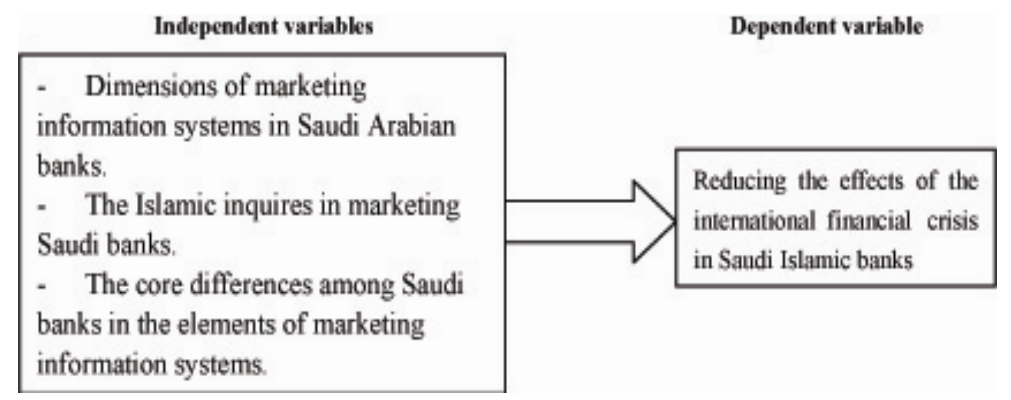

Figure 1. The virtual sample of the study

\section{The Theoretical Framework and Previous Studies}

\subsection{Marketing Information System: Definition, Significance, and Its Role in Islamic Banks}

Applying marketing information systems on business organization in general and Islamic banks in particular has become extremely important. This matter needs a huge quantity of information and data to be able to manage marketing systems starting from taking decisions in business organizations. Marketing information system is the main priority of information that helps the Islamic banks in achieving development as well as meeting the international financial crisis.

There are many definitions concerned in marketing information systems. These definitions are considered as important in marketing information system represented by devices, procedures, human resources necessary for collecting, classifying, and analyzing data. The step is to introduce them to decision makers (Hashim, 2007). Due to this definition, the organizations' role is to enhance making marketing decision and managing it efficiently in the face of problems and crises in business organization.

Marketing information system has taken important place in Islamic banks. It helped marketing manager due to the Islamic approach in developing the process of marketing planning, pricing, taking the strategic decisions, predicting the position of market, and the potential to meet the challenges where the financial crisis is the most important. It contributes in evaluating the performance of Islamic banks accurately. The significance of marketing information system in the Islamic banks has become important because of its necessity to transform from local market to regional and international market and it makes the management predict the crisis they would face (AL-Sheikh, 2007).

Marketing information systems (MIS) are considered important because of their benefits presented through the daily, monthly, and annual reports which help in taking correct marketing decisions to face crisis and deviations occurred in business plans.

Marketing information systems are consisted of completed sub-systems which make information flows to marketing managers. The necessity of information was studied in accordance with managers and planning for systems related to marketing information to confirm these needs. One of the most components that help the 
organization to meet the financial crises: marketing planning system, the systems of internal data processing, the external records, and information analysis (Hashim, 2009, p. 63).

\subsection{The Current Crisis, International Financial Crisis from Islamic Perspective: Its Definitions and Reasons}

The current crisis has become a turning point and sudden disturbance to transform from one position to another that may be more collapsed and dangerous caused by the collapse of some systems of states, in addition to the appearance of (ISIS) as a main reason for this crises. So, the crisis is worsen and expanded at the international level as well as the level of economic sectors until the capitalist states began to intervene in supervision and nationalization to save the economies of the population. Such action is related to the fact of capitalist economies and their risks on the Islamic economy because such interference in the supervision and marketing activities is considered as one of Islamic state's duty. The Islamic marketing economy depends on moral freedom that is not connected with metal properties and usury. It is related to balance, justice and real interaction in the light of economic crisis among experience and capital beholders where the risks are divided equally between the investment processes (Ali, 2009).

It can be said that the nature of capital economy and its branches is the main reason of crisis because it is an economy based on many facts that are violated from Islamic jurisprudence especially marketing the financial derivatives illegally and in unacceptable way. The prophet Mohammad (peace be upon him) prevented in speculative financial transactions and long run contracts and all the associated financial derivatives, because it is a kind of ambiguity, which means ignorance and put money of the market in risk. Due to the decision issued from The Islamic Fiqh Council number 7/1/65 on 1992 Islam has urged on working to find the alternatives of financial derivatives that achieve same benefits to be confirmed with the Fiqh settings in Islamic marketing and tradable in stock of exchange and Islamic banks; in addition, they achieved features of financial derivatives.

The trend toward factoring increased. It is considered as a reason of financial crisis which means adding ways to the financial report that has no real assets so the crisis has been exacerbated. Relating to the Islamic structures, we will find that this kind of factoring shall be implemented in asset not in dept, and this was assured by the decision of council number 92/4/11 on 1988 where dept factoring is considered a kind of postponed debt. The Islamic factoring can be utilized and marketed as a financial tool to serve all financial organizations as far as possible to postponed dept. Researchers have seen that one of the most factors of crisis due to Islamic Shareia is usury. It is not legally accepted. This has exacerbated the mortgage crisis. One example on economy and Islamic marketing usurious interest as it has been done in Japan, America and Europe where usury was lower than 1\% and that was confirmed by the decision number 52/1/6 issued in Islamic Fiqh council that was held in March, 1999 which has enhanced the re-sell of the property (Khalidi, 2013).

\subsection{Banks Working in Saudi Arabia: Importance, Marketing, and Its Effect on Financial Crisis}

Islamic banking sector plays an important role in Saudi economy. The importance of this sector has been increased recently. Before talking about the reality of Islamic banking sector in Saudi Arabia, the social and economic importance of Islamic banks and the mechanism of marketing in the Arab and Islamic world must be notified. The number of Islamic banks has reached to 320 organizations and the overall capital was 520 billion dollar. Growth of managed funds volume stood at more than 13\%. It must be noted that Islamic banks have been characterized in the creativity of financial service marketing particularly in the beginning of the third thousand where the financial crisis have occurred in the first decade. The funds of Islamic banks in the Arabian states have reached to $7.25 \%$ from the total of Arabian banking funds on 2000 to $14.29 \%$ at the end of 2009 . They were able to achieve the greatest growth among the traditional existent banks, and their funds reached to more than 120 billion dollar in 2015. It was able to achieve qualitative leap in marketing high quality banking services. The result was the excellence of these banks that have positive effects by getting the least loses and the least of the global oil price, the budgets have been verified in Islamic banks in general and the banks in Saudi Arabia in particular because of the legal instructions that make clients employ capitals and conduct investment with Islamic banks (AL-Elian, 2010).

Saudi Arabia is characterized in the existence of Islamic banks which work in accordance with Islamic Shareia. They were established to serve the needs of clients nevertheless the usury banks. Three banks have been randomly selected by using a simple method.

Table 1. The banks working in Jeddah

\begin{tabular}{lll}
\hline AL-Rajehi bank & Al-Jazera bank & SAMBA bank \\
\hline
\end{tabular}


There are many definitions for the idiom of Islamic banks. The Islamic bank can be defined as: the bank that is commitment in applying the structures and instructions of Islamic Shareia in all commercial, investment, and financial transactions by applying the concept of financial intermediation based on the principle of participation in loss and achieving benefits and not to deal with usury (AL-Khasawneh, 2008). Due to that definition, Islam has prevented marketing of usury and dealing with all its kinds in all Islamic banks as that mentioned in the verses of (AL-Baqra, 275) and (AL-Omran, 130).

The banks working in Saudi Arabia were able to prevent two problems including poverty and unemployment and reduce the effects of the current crisis. The employers who work there reached to (2631) and they were characterized by mostly adequate experience. They also hold different scientific qualifications due to majors and university degrees to provide the best marketing and financial services locally and internationally. In addition, they provided all facilities and banking and financial procedures due to Islamic structures easily. The vision of the banks working in Saudi Arabia as the international Islamic banks is to achieve the comprehensive development for the Saudi community. The three Islamic banks contribute in reducing developmental balance among governorates of the kingdom through the affiliated branches and offices and comprehend number of employers that have not been demobilized due to the financial crisis that hit the economies of the whole world, the Islamic banks market their services by a set of rules and principles that are consistent with the Islamic economics (Swan, 2011), the most importantly were:

1) Succession in the earth, God created human on the ground, a successor of one God Almighty says in (AL-Baqra, 162).

2) Lack of compactness: the Islamic economy urged the lack of compactness of money to be spent only in good outlets as in the verse of (AL-Tuba, 34). In the light of current financial crisis, the banks working in Saudi Arabia need to establish effective marketing plans which are able to deal with the challenges of financial crisis, activate the advertisements and collect marketing data and information with the aim to collect savings from individuals rather than compactness in line with religious awareness campaigns.

3) Conscience monitoring for the individual by the Creator Almighty for all his/her actions according to the verse of (AL-Hajer, 4). If the one felt that he/she is observed, he/she would feel the money he spends is monitored as mentioned in the verse of (AL-Hajer, 93). So, from here religion prohibits all images of selling debt with debt.

As mentioned above, marketing information system enhances the position of Islamic banking market including the Islamic banks which are based on facts that distinguish them from usurious banks that hit the capitalist economy; here are the most important of facts:

1) Launching the marketing process in Islamic banks from only the two principles of lawful and unlawful (Halal and Haram). The participation of the loan borrowers is incentive to work in the Saudi Islamic banks to lawful and to obtain fair benefit to trend investment for producing real sales and services that Muslim needs to utilize them in the tracks of comprehensive development.

2) The absence of usury interest financing as mentioned in the verse of (AL-Baqra, 278). The lawful money is that brought by extracting effort. Dealing with usury in the traditional banks is the reason of the financial crisis where the traditional banks sought for establishing a system of marketing information to attract the clients, and such an action is prohibited in Islam.

\subsection{Previous Studies}

Recently, arguments and talks on the international financial crisis increased, and thus hundreds of local and international conferences were held to shed light on the effects of this crisis on the Islamic economies, however, such conferences that deal with the financial crisis are rarely held in the Kingdom of Saudi Arabia (unavailable), both researchers could execrate the literature of previous studies as following:

1) The study of (AL-Safi \& Matarneh, 2009) "The Islamic economy in meeting the financial crisis between theory and practice"

The study depends on the analytical approach by explaining the theoretical structures and the practical practice. The study aimed to identify the role of Islamic economy in meeting the financial crisis and to explain the main reason of the crisis. The study also has clarified the results and the most important solutions that may be adopted by the Islamic banks to prevent the negative effects of the crisis where activating the tools of Islamic investment in different countries are the most important.

2) The study of (Caruana \& Farzad, 2009) "The effects of internal marketing on organizational commitment in Islamic banks: an empirical study in Iran" 
The study aimed to identify the economic importance of Islamic banking sector and the role of internal marketing in raising the sufficiency of Islamic banking. The study depends on the city of Isfahan. A random sample has been selected reached to (54) branches of banks. The study has concluded the following: the necessity of practical applying for the strategies of internal marketing in order to activate the role of commitment and achieve the flourishing and development in providing the marketing and banking services and adopting with different crisis.

3) The study of (Ahmad, 2010) “An Empirical Investigation of Islamic Banking in Pakistan based on perception of service quality"

The study aimed to appear the quality of Islamic banking service in the light of Pakistani environment. A random sample of clients was selected. The results have shown that the significance of Islamic banks in assimilating the biggest number of clients. In addition, there are core differences in realization of the Islamic banking service due to gender. This study has been taken because it recommended mixing between the Islamic theory and the practical applying in Islamic world. It was moved away from the marketing information system and applied in an economy system which is somehow different in its components from the Jordanian economy.

\subsection{What Distinguishes the Current Studies from the Previous}

This study has included the three Islamic Saudi banks where Jordanian-Dubai Islamic bank is the most important because it is new in Jordan.

This study has sought for contributing in achieving the addition and scientific enrichment as it is one of rare studies discussing the role of Islamic banking marketing to meet the current financial global crisis through the dimensions of marketing information systems.

\section{Data}

\subsection{The Population and the Sample of the Study}

Population of the study presents all the employees working in marketing services at the Islamic banks including (AL-Rajehi, AL-Jazera, \& SAMBA) in Jeddah. The data was collected during the duration of (20/8-20/9/2012). The number of employees was 230, and an appropriate sample (intentional) has been selected. It was estimated by 105 forming $(105 \div 230=0.456)$ from the total of population subjected to the study. 89 questionnaires were retrieval forming 0.848 and 75 of questionnaires have been undertaken for analytical issues forming 0.843 . Table 2 is a description of the sample population of the study in Saudi Islamic banks (Anderson, 2013, p. 51), whereas Table 3 explains distributing the sample of the study due to the number of demographic variables.

Table 2. Sample population of the study for banks working in Saudi Islamic due to postural statement

\begin{tabular}{llllll}
\hline Name of Bank & \multicolumn{2}{l}{ Number of employees \& ratio } & Number of branches \& offices & The size of sample selected & Undertaken to analysis \\
\cline { 2 - 4 } & Number & Ratio & & 71 & 50 \\
\hline AL-Rajehi & 1785 & 72.38 & 59 branch, 159 office & 10 & 7 \\
AL-Jazera & 156 & 6.33 & 4 branches and offices & 24 & 18 \\
SAMBA & 525 & 21.30 & 28 branches and offices & 105 & 75 \\
Statistical Total & 2466 & 100 & 106 & \\
\hline
\end{tabular}

The sample of the study has been calculated by dividing the number of employees in every bank on the total of employees in the whole banks 2466 multiplicities with the size of the sample and it is (105) (Sekeran, 2005).

The results of Table 2 have indicated that the highest percentage of scientific qualification category was 69.33 for Bachelor and this is an indicator that banks working in Saudi Arabia are interested in hiring scientific qualifications are able for marketing the Islamic banking as enhancing the place of bank before the global challenges. According to the variable of experience, the study has proven that $50.67 \%$ from the size of the sample reached to the category whose experience was 5-10 years. The experiences between the categories of (less than five years) and (more than 10 years) are equal. This is an indicator that banks working in Saudi Arabia are considered a new business market on local and international levels. Due to the third final variable, it was cleared that half of the sample reached to $54.67 \%$ for the category of ( 27 years and less than 40 years) whereas the lowest percentage was $18.67 \%$ for those whose age reached to 39 years and that confirms the law of Social insurance which motivates the early retirement after 15 years of service. 
Table 3. Distributing the sample of the study due to the scientific qualification, years of experience, and the age of the study sample

\begin{tabular}{lll}
\hline Demographic variable & Number & Relative importance \\
\hline Scientific qualification & 19 & 25.33 \\
\hline$\quad$ Less than diploma & 52 & 69.33 \\
- Bachelor & 4 & 5.33 \\
- High studies & & \\
\hline Total & 75 & 100 \\
\hline Year of experience & 18 & 24.00 \\
\hline$\quad$ Less than 5 years & 38 & 50.67 \\
$-\quad$ From 5- 10 years & 19 & 25.33 \\
$-\quad$ More than 10 years & & \\
\hline Total & 75 & 100 \\
\hline Age $\quad 20$ & 26.67 \\
\hline$\quad$ Less than 27 years & 41 & 54.67 \\
From 27- 40 years & 14 & 18.67 \\
\hline$\quad$ More than 40 years & & \\
\hline Total & 75 & 100 \\
\hline
\end{tabular}

\subsection{Sources of Data Collection of the Study}

The study depended on two types of sources:

- The secondary sources: they have been collected from the scientific researches, the banking encyclopedia, the conferences and seminars, and all books of Islamic economy and what is related to the Islamic banking marketing. In addition to the perspective of the two researchers about Islamic banking marketing.

- The primary sources: they are represented by the questionnaire designed to measure a set of independent variables and their effect on the dependent variable in aim to test hypothesis and reach to results and recommendations.

\subsection{Designing the Tool of Data Collection}

The tool of data collection has been designed with the aim to measure the effect of independent variable on the dependent one; in addition, identify the perspectives of employees in marketing services at Islamic banks and their impact on causes of the international financial crisis.

\subsection{The Used Statistical Methods}

It was used the statistical program (SPSS) and the descriptive analysis by measuring central tendency and dispersion measures for the issues to process data and test the hypothesis, (ANOVA), (simple regression), (multiple regression) methods were applied to measure the strength of relation between the independent and dependent variables. The validity and credibility of the study tool was verified by distributing the questionnaire on a number of arbitrators in the field of Islamic banking marketing. Their notes have been taken and the questionnaire has been edited due to these notes. The credibility of the tool has been measured by applying the equation of Cornbach alpha to identify the degree of using the study questionnaire in measuring the effect of the independent variables on the dependent ones. It was cleared that the results were accepted $87 \%$ as it was higher than $60 \%$ for all the variables of the study in addition to the data which achieved the feature of natural distribution due to the certified test (Malhotra, 2004, p. 390).

\section{Results and Discussion}

Contrast of the availability of marketing information systems at Islamic banks (the third hypothesis).

This paragraph aims at testing the extent of contrast the availability of marketing information systems at Islamic banks Table 4 shows the means connected to the availability of marketing information systems in addition to the percentage of response for every bank (Anderson, 2013) 
Table 4. The averages, the percentage response, and the classification of Islamic Saudi banks to reduce the effects of financial crisis

\begin{tabular}{llll}
\hline Islamic banks & Mean $(\mathrm{x})$ & Response Ratio $(\%)$ & Ordinal Role \\
\hline SAMBA & 1.89 & $91.4 \%$ & 3 \\
AL-Rajehi & 2.21 & $98 \%$ & 1 \\
AL-Jazera & 1.98 & $96 \%$ & 2 \\
\hline
\end{tabular}

The statistical result of Table 4 shows that there is a contrast and difference in the availability of marketing information systems at Islamic banks. (AL-Rajehi) bank has taken the first place so that enhances its ability to meet the financial crisis, the average was 2.21 and the percentage response was (98\%). Whereas (AL-Jazera) bank has taken the second place (1.89) (91.4\%), this may reduce the number of offices and branches in this bank. So, hypothesis (3) has been accepted.

The statistical results and the analysis of correlation relations between the independent variable of marketing information system and reducing the effects of the financial crisis that there is a positive relation between the two variables in the banks working in Saudi Arabia where $(\mathrm{R}=0.68)$ and the level of significance was $5 \%$.

Table 5. The statistical results for testing variables of marketing information system at ( $\mathrm{SIG}=5 \%$ )

\begin{tabular}{lll}
\hline The variable of (MKIS) & The indicators of financial crisis (the total indicator) R & Sig. \\
\hline MKIS & 0.68 & 0.00 \\
\hline
\end{tabular}

The results of multiple regressions between the variable of marketing information system and the variable of meeting the international financial crisis price have shown that there is a positive statistical significant relation. The correlation coefficient reached to $68 \%$. This indicates that existing marketing information systems contribute in determining the requirements of management of the international financial crisis in the banks working in Saudi Arabia and their phases through applying the marketing information system and enhance the situation of Islamic banks in taking decisions that reduce the effects of the international financial crisis, in particular, the base that the Islamic banks started from is the prohibition of dealing with usury. The results reflect the acceptance of the hypothesis (1): There is a significant correlation acceptable relation between marketing information system and the ability of Islamic banks to reduce the negative effects connected to the financial crisis. The reason is that the Islamic bank accepts money and deal with it on the basis of (kharaj) (security and pays for losses of merchantable and invested in accordance with the purposes and provisions of the law dealing with money and employment on the basis of Islamic financing (AL-Elian, 2012).

To clarify the correlation relation among the variables of the study and the dependent variables, it was noted that there is a significance effect for the dimensions and marketing information system to challenge this crisis in the banks working in Saudi Arabia. The statically results in Table 6 have indicated that the value of coefficient of determination reached to $(\mathrm{R} 2=15.5)$ which means $(15.5 \%)$ of contrast of crisis is related to the role of marketing information system in reducing its effects. $(84.5 \%)$ is related to random variables that are related to the Islamic rules where the Islamic banks depend on. These variables are considered a competitive advantage for the Islamic banks to meet the results of the crisis and they are not included in multiple regression samples. What enhances this hypothesis is that the value of (fc) reached to (16.84) and it was more than (ft) at the significant level (5\%). (b) reached $(57.1 \%)$ and $(\mathrm{t})$ was $(1.96)$, thus there is an effect for the marketing information systems to reduce the effects of the international financial crisis. So, the hypothesis (4) was accepted indicating that there is a significant for the dimensions of marketing information systems in banks working in Saudi Arabia to reduce the effects of the international financial crisis and this result is consistent with the study of (AL-Shomari,2009,33).

Table 6. The statistical analysis results of the dimensions (MKIS) to reduce the effects of the international financial crisis in banks working in (KSA)

\begin{tabular}{lllll}
\hline Independent variable & R2 & B & Tc & Fc \\
\hline Dimensions of (MKIS) & $10.0 \%$ & 0.571 & 4.32 & 13.37 \\
Islamic requires in marketing the Islamic banks. & $12.3 \%$ & 0.523 & 4.11 & 10.02 \\
$\begin{array}{l}\text { The core differences among Islamic banks in components } \\
\text { of (MKIS) }\end{array}$ & $14.06 \%$ & 6.54 & 3.97 & 11.22 \\
\hline
\end{tabular}


The results of Table 6 have shown that there are Islamic requirements in the banks working in Saudi Arabia to reduce the effects of the international financial crisis. $\left(\mathrm{R}^{\wedge} 2\right)$ reached $12.3 \%$. This indicates how much the Islamic requirements deal with trading, speculation, and not to deal with usury occurred in the management of financial crisis and reduce its effects. The value of $(\mathrm{Fc})$ calculated 10.02 and it is higher than (ft) 6.02 and (Sig) is less than $5 \%$. We find an effect for the Islamic requirements to reduce the effects of the international financial crisis on Islamic banks. Hence, the hypothesis (2) is verified.

The hypothesis is related to the core differences among the banks working in Saudi Arabia to search for the components of marketing information systems. The statistical results of Table 6 shows there is a significant effect for the core differences in the Islamic banking marketing to reduce the effects of the international financial crisis. The results of regression analysis indicated that the effected relation was significant. $\left(\mathrm{R}^{\wedge} 2\right)$ was $14.06 \%$ that means 0.1406 from the explained differences in the management of global financial crisis related to the effect of marketing information systems. Whereas $86 \%$ related to random variables can't be controlled or they aren't included in the contents of the current study. (F) was 11.22 which is higher than (F) tabulated 6.11 at the statically significance 0.05 . There is an effect for the core differences among the banks working in Saudi Arabia in the components of marketing information systems where the most important studies of marketing and methods of marketing intelligence form an Islamic perspective to reduce the effects of the international financial crisis. What enhances this result is (B) that reached to 6.54 that means when the core differences increase among the banks working in Saudi Arabia in adopting the dimensions of marketing information systems that will reduce the effects of financial crisis and reduce its negative results (Ahmed, 2010). The study of (Ahmed) assured the current study.

In the light of the huge expanding in all over the world especially in Islamic banks, the banks working in Saudi Arabia were the least economic sector to be effected in the international financial crisis which bankrupted many traditional banks in spite of adopting the system of marketing banking tools and information marketing system. However, the tools of Islamic financing and banking marketing could reduce the percentage of risk due to its connectivity with real economy and being further from the process accompanied with high risks. In addition to that, financing methods in banks working in Saudi Arabia has a large acceptance among the different sectors of the state because they confirm the structures of Islamic economy which forms a basic reference in the kingdom (Oriqat \& Aqel, 2010). In addition to the role played to allow the financial references in organizations and Islamic banks to finance in all regions of the kingdom.

The results confirmed that the nature and the features of Saudi Islamic banks due to these banks don't deal with usury, they are commitment to the structure of Halal and Haram (lawful and unlawful) in dealing with all economic activities. The Islamic banks have sought for developing awareness of saving and encouraging investment through finding and marketing the chances and investment statements appropriate with all organizations and levels of community as mentioned in the verse of (AL-Nessaa, 29).

The Islamic investment systems have multiple formulas and statements including: profiting, speculation, participation, leasing, and other Islamic formulas acceptable for applying and marketing used in all activities and times.

\section{Recommendations}

The results and the analysis of the study have shown the following.

- Marketing the use of Islamic financing instruments in the context of modernization of the Islamic financial management in terms of the issuance of uncertainty as one of the mechanisms through the diversity of financial instruments used to limit the effects of the international financial crisis.

- Issuance of Islamic instruments and activation marketing and work to provide a marketing information system of all its technical, financial and legal aspects, as well as to determine the appropriate mechanisms and consistent with the norms of Islamic Shareia legislation as well as Saudi Arabia at the same time.

- Islamic banking is hiring marketing specialists, academics and workers in the Ministry of Awqaf and the Central Bank and that of competent authorities which are able to deal with the financial crisis management.

- Working to develop the abilities of employers in the managements of marketing and banks working in Saudi Arabia to warm the marketing environment for Islamic banks and working to find particular systems to provide information to deal with the financial banking system including the studies of marketing, knowledge.

- $\quad$ The need to work on marketing the Islamic banking theory for foreign economies. 
- The study has recommended conducting a number of studies related to other variables for the dimensions of financial Islamic marketing and the reasons of the international financial crisis.

\section{References}

Ahmad, A. et al. (2010). An Empirical Investigation of Islamic Banking in Pakistan Based on perception of service quality. A Frican Journal of business Management, 4(6), 1184-1191. Retrieved from http://www.academicjournals.org

Al-Khasawneh, A. S. (2014). Islamic banks, i, Amman, the wall of the world of the book and the world of the book talk (pp. 18-210).

Anderson, D. et al. (2009). Statistics for Business and Economics (10th ed., p. 51). Thomson South-western.

Armstrong, G., \& Kotler, P. (2007). Marketing: An Introduation (8th ed., p. 30). Pearson prentic Hall.

Bajpai, N. (2010). Business statistics (pp. 31-34). Pearson education-prentice Hall.

Farzad, N. (2007). The Effect of Internal Marketing on Organizationlal Commitment in Iranian Banks. American Journal of Applied Sciences ,5(II), 1481-1485. Retrieved from http: www.scipu6.org/

Hunaiti, H. (2007). Sample sale and securitization: A Case Study of Islamic banks. Unpublished PhD thesis, The Arab Academy for Banking and Financial Sciences.

Ismail, H. et al. (2009). Marketing in Islam (pp. 94-96). Dar: AL-Bazawi for distribution, Amman.

Khalidi, A. F. (2013). Measuring the level of image Islamic banking services operating in Palestine from the customer point of view. Unpublished Master Thesis, the Islamic University of Gaza.

Malhotra, N. (2008). Marketing Research (5th ed.). New Jersy: Prentic Hall. http://dx.doi.org/10.1108/S1548-6435(2008)4

Olayan, A. (2010). The Shari'a Islamic banks work. Unpublished Master Thesis, An-Najah National University.

Rifai, H. (2011). The role of Islamic economic thought in the management of the current financial crisis. The Conference of the global financial crisis and how to address them from the Western and Islamic economics perspective. Tripoli, Lebanon.

Sheikh, D. (2012). Global Financial Crisis: Implications and Solutions. Conference of the global financial crisis and how to treat them from the west and the Islamic economic system perspective. Tripoli, Lebanon.

\section{Copyrights}

Copyright for this article is retained by the author, with first publication rights granted to the journal.

This is an open-access article distributed under the terms and conditions of the Creative Commons Attribution license (http://creativecommons.org/licenses/by/3.0/) 